\title{
Chapter 4 \\ Employee Representatives in Estonia. How are they Perceived and what are the Expectations by Employers?
}

\author{
Mare Teichmann and Merle Lõhmus
}

\subsection{Historical Context of the Labor Movement in Estonia}

The Russian Revolution of 1905 was said to be a major factor leading to the Russian October Revolution of 1917. The events of Bloody Sunday triggered a line of protests in Russia and it was also influential in Estonia. So, Estonia's trade union movement began in 1905 with the revolutionary events organized by local left oriented revolutionaries.

In response to workers organizing, the employers organized themselves as well. In 1917 the employers' professional associations (Association of Estonian Manufacturers) were formed in Tallinn and Tartu. The Association of Estonian Manufacturers ceased operations ordered by the Soviet authorities in 1940.

In February 1918, after the collapse of the peace talks between Soviet Russia and the German Empire, the Bolshevik forces retreated to Russia. Between the Russian Red Army's retreat and the arrival of advancing German troops, the Salvation Committee of the Estonian National Council issued the Estonian Declaration of Independence on February 23, 1918. A military invasion by the Red Army followed a few days later, however, marking the beginning of the Estonian War of Independence (1918-1920). In all this chaos and in conditions of Estonian War of Independence, in autumn 1919 the first Estonian Trade Unions congress took place. The congress clearly declared their unwillingness to support an independent Estonian state but congress delegates saw Estonia as a part of the Soviet Russia. On the second day of the Congress, the statements made by anti-independence were denied. In 1931 a new left-oriented trade union center was founded- Tallinn and Harju County Central Council of Trade Unions.

M. Teichmann $(\varangle) \cdot$ M. Lõhmus

Tallinn University of Technology, Tallinn, Estonia

e-mail: mare@pekonsult.ee

M. Lõhmus

e-mail: merle.lohmus@ttu.ee 
In 1936 the Estonian government, however, blocked the trade union movement development and created the government-friendly labor movement. In 1938, the "Employee and Associations Act" was introduced. This act allowed establishing a local or national professional association, but only one professional association for each profession, the parallel organizations were not allowed. Political activities and all activities affecting the country's defense and foreign policy relations were banned.

During World War II the trade union activities were suspended. In 1948 the Estonian SSR Council of Trade Unions was reorganized under subordination of the Soviet Union's Central Council of Trade Unions. Thus, during the Soviet occupation in Estonia there were no independent trade unions. Trade union activities were rather formal, managed and completely controlled by the Communist party.

In 1989 the Estonian SSR Council of Trade Unions XX Congress announced them as an independent trade union organization. Since 1990, public and private organizations began to form trade unions. After the Soviet period, the employers' organization was formed in 1991 and in 1995 it was reorganized as the Estonian Employers' Confederation.

The unions in the past provided the only channel for employees' representation, but now there is the legal possibility of elected employee representatives (ERs) being in place alongside the union. Main employee representations at the workplace were done through unions, and since 2007 independent ERs can be elected as well ${ }^{1}$. The Estonian law provides for both union and works council structures to exist at the workplace at the same time. On the other hand, collective bargaining is a legal privilege and an exclusive right for unions and not of the works council.

When we compare the Estonian unions' membership rate with other EU countries' unions' membership rates, we must admit that the Estonian employees are not highly represented by the union (see Fig. 4.1).

Unions represent only $8.1 \%$ of the Estonian workforce. In other words, the overwhelming majority of employees $(91.9 \%)$ are not represented by the unions (OECD Statistics in Fulton 2011). Moreover, like in many EU countries, there's a continuing downward trend of union membership in Estonia (see Fig. 4.2).

Due to the Estonian trade unions' history and a low reputation from the Soviet period, both the employees and employers assessing works councils are more democratic and innovative than the unions. Figures also make clear that works councils enjoy a higher popularity in Estonian enterprises than unions (Statistics Estonia 2011). Comparably, $6 \%$ of the Estonian organizations have unions, and twice as many organizations $(13.3 \%)$ have works councils.

The 2009 Statistics Estonia survey shows that $32.7 \%$ of employees in organizations employing five or more employees are covered by collective agreements.

\footnotetext{
${ }^{1}$ Directive 2002/14/EC of the European Parliament and of the Council of 11 March, 2002 establishing a general framework for informing and consulting employees in the European Community-Joint declaration of the European Parliament, the Council and the Commission on employee representation (Official Journal of the European Communities, L 080, 23/03/2002, pp. 0029-0034), in 2007 Directive 2002/14/EC adapted in Estonia.
} 


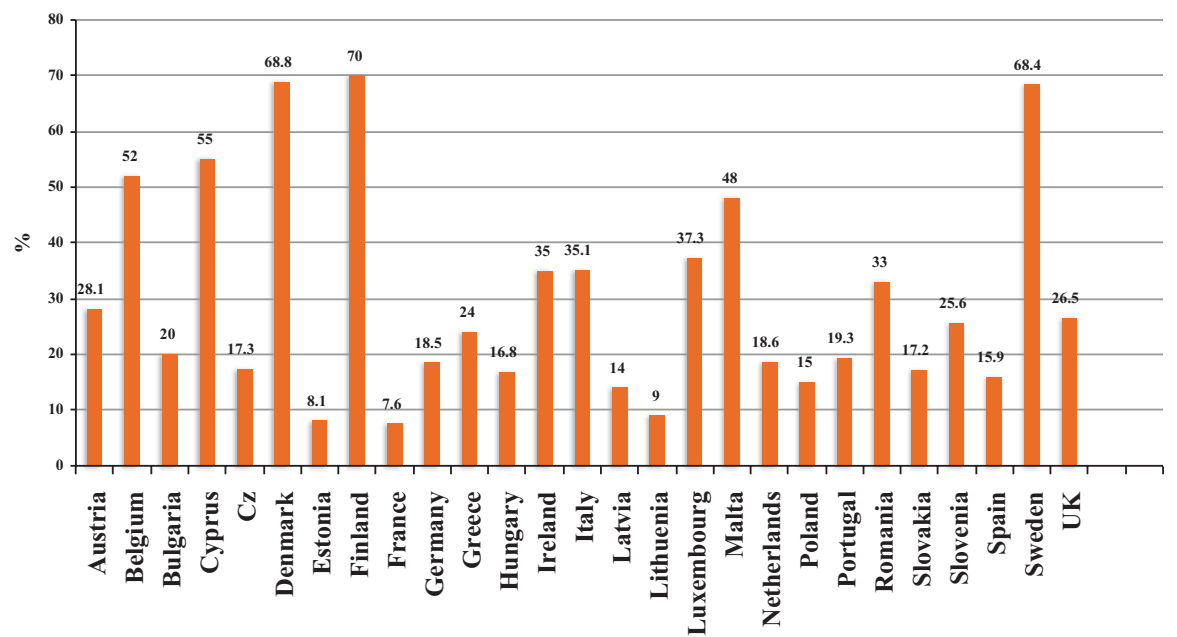

Fig. 4.1 Union's membership in EU countries (Source: OECD Statistics 2013)

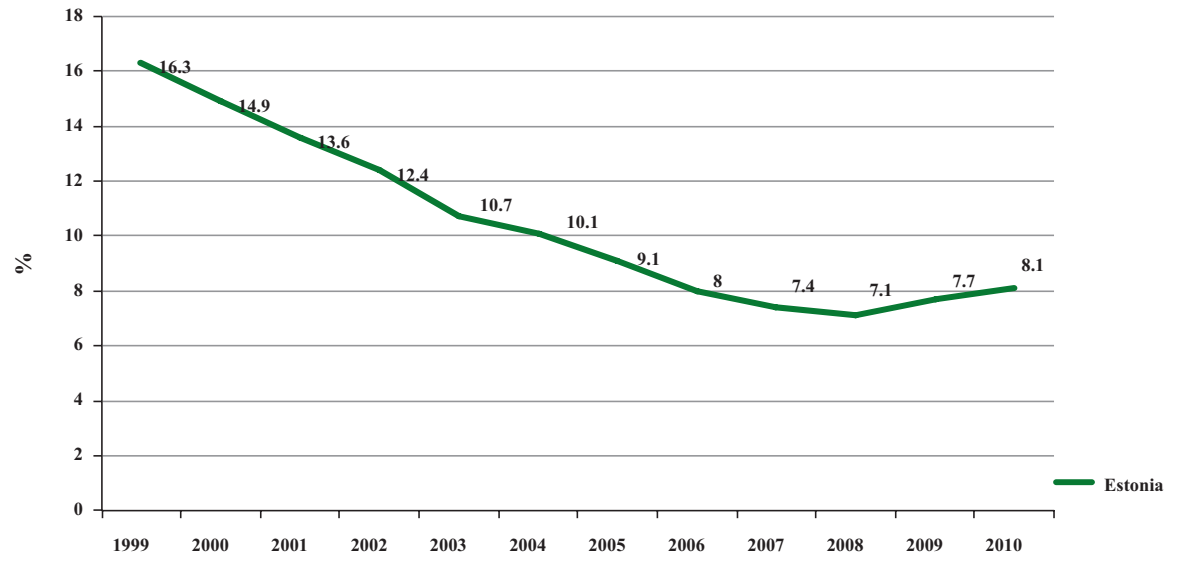

Fig. 4.2 Estonian trade unions membership (Source: OECD Statistics 2013)

However, still the majority of employees are not represented at all, not in unions and nor in the works councils. Thus, working conditions, and in particular pay, are fixed in direct discussions between the employer and the individual worker.

In the next section we summarize the most relevant indicators pointed out by the employers in the interviews regarding the profile of the ERs. In order to better understand these opinions, we start by giving an overview on the structure of the industrial relations system in Estonia. 
The main legislative document regulating employment relations in Estonia is the Occupational Health and Safety Act, passed on 16 June 1999. This act states that besides the trade unions there are three kinds of bodies taking care of the working environment and employees' well-being. These bodies are:

1. The working environment specialist is an engineer who is competent in the sphere of working environment or any other specialist in an enterprise who has received training concerning the working environment and whom the employer has authorized to perform occupational health and safety duties.

A working environment specialist is a full-time employee and is paid as any other employee for his/her work. Generally speaking, a working environment specialist works under the supervision of the HR manager.

2. A working environment representative is a representative elected by employees in occupational health and safety issues, and his or her term of authority is up to four years. In an enterprise which employs 10 employees or more, the employees shall elect one working environment representative from among themselves. If an enterprise employs less than 10 employees, the employer is required to consult with the employees in matters of occupational health and safety.

A working environment representative is an ordinary employee, who performs his/her functions besides his/her ordinary work and is not to be paid for the representation tasks.

3. A works council is a body for co-operation between an employer and the ERs, which resolves occupational health and safety issues in the enterprise. In an enterprise with at least 50 employees, a works council shall be set up at the initiative of the employer and it shall comprise an equal number of representatives designated by the employer and representatives elected by the employees. The council shall comprise at least four members and the term of their authority shall be up to four years.

A works council shall:

1. regularly analyze the working conditions in the enterprise, document-developing problems, make proposals to the employer for the resolution thereof and monitor the implementation of adopted resolutions;

2. participate in the preparation of an occupational health and safety development plan of the enterprise, and in the preparation of plans for the reconstruction or repair of the enterprise and for technological innovations in the enterprise, and of other plans;

3. examine the results of the internal control of the working environment in the enterprise and, if necessary, make proposals for the elimination of deficiencies;

4. analyze occupational accidents, occupational diseases and other work-related illnesses, and monitor the implementation of measures for the prevention thereof by the employer;

5. assist in the creation of suitable working conditions and work organization for female employees, minors and disabled employees. 


\subsection{Current Situation of the ERs. What do Human Resources Managers Say?}

In order to examine the role and impact of employee representative bodies on regulation of industrial relations in Estonia, ten interviews with large companies HR top managers were carried out in 2013. Interviews focused on experiences and expectations of Human Resources Managers (HR) on ERs' roles, attitudes and competencies to act as partners in social innovation.

The following conclusions are based on the outcomes of these ten interviews. Respondents were between the age of 25 to 69 , nine of them female and one male, with experience from one up to 18 years in companies. Interviews focused on their perception of ERs' role, competences, attitudes and future development needs.

There are six main concerns: need for improvements in employee representatives professionalism, need for more cooperation-oriented attitudes of the employee representatives, need for building up stronger mutual trust, need to rise works council's prestige and need to have better knowledge about EU policies on employment relation issues. These concerns are discussed in detail below.

Need for professionalism There is a general agreement among employers on the need to professionalize the ERs role and training especially on technical competencies.

According to the law, the ERs have to go through the 24-hour training organized by the Labor Inspectorate (the Labor Inspectorate is a government agency operating within the area of government of the Ministry of Social Affairs). The working environment specialist and/or the HR manager give the ERs additional information, if it is needed. If there is a need for additional training in legislative regulations, the company normally will support it by giving free training opportunities to ERs. But — as it has been mentioned by respondents - the lack of knowledge and skills about work environment issues is not the main problem as this is mostly the attitude of ERs. ERs know the requirements to the work environment as well as the current situation in the organization, but they don't act because of the lack of the belief that they can make any changes (low motivation) or there is a deficit in negotiation and conflict resolution skills. Although management knows that the encouragement of ERs is necessary and training in negotiation skills and conflict resolution is needed, mostly management does not take responsibility.

Attitudes of ERs The attitudes of the ERs are problematic. ERs are often disinterested.

To be honest - elections of WC members are superficial; most people don't want to be the representatives and the elected members are not very motivated as employee representatives (HR manager, large manufacturing company).

Additionally, managers perceive a lack of commitment and involvement with the organization's strategy from the ERs' side. The industrial sector is especially concerned about the lack of representation of the overall workforce. According to HR 
managers, in this sector the majority of ERs are working for their self-protectionism instead of being more flexible, working on anticipation and prevention of conflicts.

Low mutual trust During the interviews, some uncertainty and skepticism from the side of employers showed up when speaking about mutual trust between management and ERs. In most cases respondents had difficulties to estimate mutual trust.

Estonian managers point out that ERs lack the characteristics that they consider as antecedents for creating a trusting relationship, such as the ability or control of specific competences; benevolence or considering that ERs would do good to the organization; and integrity, or that the ERs adhere to a set of principles that the managers find acceptable such as reliability, fairness, justice and consistency. Especially managers in the industrial sector agree that both ERs and management distrust each other. Some of HR managers indicated that as there have not been visible problems with the trust so far there is no any need for improvements.

There has not been problems with the trust so far. Thus I do not see any need for improvement (HR manager, educational sector).

In other cases improvements in relationship and trust building between management and works council or ERs were admitted, as well as the need for improvement of communication between management and employees.

Lack of competencies Concerning the competencies, there is a general agreement that the level is too low in some competencies. In the interviews and in the surveys, managers believe that ERs lack the basic competencies necessary for their role and for successful negotiation. These competences are: business orientation, strategic thinking, proactivity, innovation and analysis. All of the sectors agree that ERs should be more innovative and adapt to the evolution of the company and sector.

The education sector proposes that the ERs' competences are on a sufficient level. The industrial sector HR manager suggests that training should be systematized and oriented to the professionalization of these experts. At the same time employers are not ready to develop these competences offering ERs in-service and/ or off-service training.

Answering to the question about further training needs of ERs, the HR manager from the industrial sector made the statement:

There is an urgent need to give training with much higher quality, but it is not the employer's responsibility to offer training on these competences because the skills and knowledge would be too on-sided in this case. True - employers haven't made any suggestions about that to the State Labor Office so far (HR manager, large manufacturing company).

However, there is not a widespread will across Estonian managers to meet and work with ERs who are prepared, competent and open to flexibility and change.

Low prestige It's also worthy highlighting the role of ER has low prestige. There is only a minority who work in an engaged and enthusiastic manner as their peers' representative. The role of the $\mathrm{WC}$ member is considered more formal and bureaucratic.

Such a low status of ERs is the result of general management pattern in the organization. Since top managers don't change their attitudes and they are continuously not interested 
in people's opinions, the role of employee representative will not be taken seriously (HR manager, educational institution).

EU policies There are no differences among the sectors; there is a general lack of knowledge on these policies among almost all of them. In some cases the knowledge exists to some extent, but EU policies do not have a remarkable influence on HR management policies in companies. The following statement of a respondent clearly represents the general opinion:

I am aware of some EU and National initiatives to promote social dialogue, i.e. equal opportunities on the labor market for disabled people; equal treatment of elder employees etc. These initiatives don't have direct impact on our organization (HR manager, Estonian owned large company).

\subsection{Perceptions of Employers on Employee Representatives. Results of the Survey}

Results are presented based on the survey among 52 Estonian employees working in HR departments (HR specialists) of different sectors, compared to the mean scores of 614 HR managers from 11 EU countries. Figure 4.3 shows graphically the mean of each variable in comparison to Europe.

One indicator of the stability of industrial relations is the trust. The industrial relations in terms of trust are also higher in Estonia $(\mathrm{M}=3.51)$ than the European average $(\mathrm{M}=3.31)$. Trust antecedents of ERs, are also significantly higher in Estonia than in Europe (ability $\mathrm{M}=3.44$ vs. $\mathrm{M}=3.14$; benevolence $\mathrm{M}=3.81$ vs. $\mathrm{M}$ =3.35; and integrity $\mathrm{M}=3.88$ vs $\mathrm{M}=3.47$ ). Even more importantly, however, the Estonian employers' representatives (HR managers) evaluate the competencies of the ERs quite highly i.e. competencies of ERs $(\mathrm{M}=2.89$ vs $\mathrm{M}=2.47)$ as well as see less diversity in competencies and attitudes of ERs $(\mathrm{M}=2.96$ vs $\mathrm{M}=3.38)$.

The study's results suggest that compared to the European average results, the Estonian ERs enjoy significantly higher empowerment by management $(\mathrm{M}=4.18$ vs. $M=3.61$ ), and on the other hand, the managers ' need for control is also significantly lower $(\mathrm{M}=2.41$ vs. $\mathrm{M}=2.86)$.

According to the survey, Estonian results hint that the conflict management is principally towards cooperative conflict management by ERs $(M=3.10$ vs. $M=2.76)$ and competitive conflict management by ERs is significantly lower than average in European survey $(\mathrm{M}=2.33$ vs. $\mathrm{M}=2.59)$. Estonian ERs task conflict is also significantly lower $(\mathrm{M}=2.51$ vs. $\mathrm{M}=2.81)$ as well as relationship conflict is also lower $(\mathrm{M}=2.12$ vs. $\mathrm{M}=2.29)$. Conflict management efficacy, and characteristics and quality of agreements in Estonia are assessed exactly on the same level than European average.

Impact by ERs on innovative issues is significantly higher in Estonia than European average $(\mathrm{M}=3.01$ vs. $\mathrm{M}=2.80)$.

These results differ largely from the results from the interviews. We elaborate on this phenomenon and its reasons in the discussion section. 


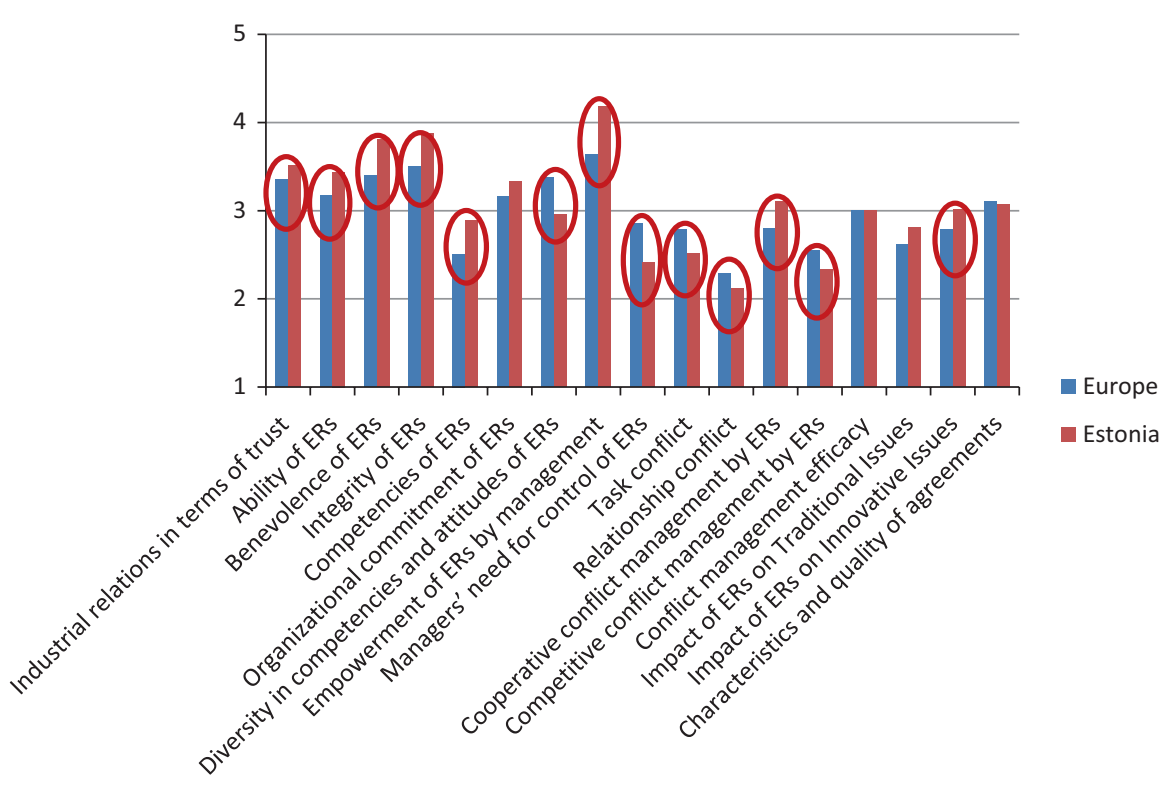

Fig. 4.3 Mean scores of main variables for Estonian and European HR managers

\subsection{Suggestions Given by Employers to Improve Social Dialogue in Estonia}

There is a major difference between organizations' approaches to employment relation's management depending on the ownership of the company. If the company is a part of some large North European corporation, the regulations for employment relations are very well elaborated. The corporative politics in employment relations are mandatory and have been applied in all corporative members including Estonian branches. Compliance of the corporate rules is followed strictly. In these cases ERs have great significance and a powerful role in the company, and managers' point of view is that there is no need for remarkable improvements in employment relations because things are going well enough.

The situation is different in smaller companies owned by Estonians. Line managers play the central role as communicators between top-management and employees. Line managers explain the goals of the organization to employees and gather information and proposals from employees; deal with the workload, workplace safety, conflict solving and other issues. Top management trusts line managers and do not see a need for a works council as an intermediating body. Organizational management should be organic, they say. The over-regulation is not healthy; it can harm the organization as the self-regulative system. Too many regulations are not good for a healthy organization.

The number of employees (subordinates) for one line manager in our organization is from 10 to 14 . This number of employees makes the communication possible with each member 
personally and with all together as a team without any formal employee representative's role. The distance to the manager is short and his/her "door is always open". Here we have a specific management culture (HR manager, Estonian owned large company).

There is no need for unions and work councils, if the managers are competent and wise enough (HR manager, Estonian owned large company).

Besides being working environment specialists, they deal with employment relations. Additionally job satisfaction enquires and work environment analyses are implemented regularly by HR departments to get feedback from employees. In many cases the company's intranet is available for all employees to share their ideas and make proposals. Therefore management does not see a need for improvements in work with ERs.

However, the suggestions made by employers in order to improve Social dialogue are summarized below.

1. No need to engage ERs in decision making. ERs do not influence the decision making process much. ERs are involved in decision-making only on the stage of the preparation of decisions as sources of information in the cases when employee's opinion is needed on specific areas (work environment matters). The current situation is satisfactory in the opinion of managers and they do not see any need for improvement. HR managers stated that there is no need to engage ERs in the company's strategically decision-making process.

2. Professionalization of the role of ERs. A suggestion given by the managers in different sectors is to professionalize the role of the ER, towards innovation and specialization.

Worker councils are dealing merely with the problems of physical work environment (work facilities, air conditioning, work safety etc.), but they do not pay much attention to the psychosocial work environment issues. As these issues are important, they consider that there should be more members in worker councils specializing on psychosocial issues at work. The idea is that the number of the worker council's members should be increased in a purpose of specialization: every member should have a responsibility according to her/his specialty; e.g. a chemist will see about chemical risk factors, work psychologist will deal with psychosocial risk factors, etc.

3. Changing attitudes. HR managers suggested that trust between the parties is not sufficient. Managers perceive that some of the antecedents to building trustthat is, ERs being able, benevolent and of integrity — are rather low.

HR managers point out that it's important to make the role attractive to competent people, including those who have a more flexible attitude.

Estonian employers believe training also influences the openness to ideas and could therefore help ERs to take into account the interest of the organization and be more flexible during negotiations.

4. Improving training quality and increasing competencies. As clearly shown by the interviews, managers believe that ERs lack the desirable knowledge, skills and competencies for carrying out their role, consequentially hindering the negotiation process. 
The 24-hour preparatory training for workers council members offered by the State Labor Office at the beginning of their ER "career" should have higher quality. So far the training has been too theoretical and non-motivating for employees. As the result of the training, the basic knowledge of ERs in employment relations and legislative regulations is rather good, but the competences like "analytical thinking" and "proactivity" are not as high as they should be. It is necessary to improve competences related to business orientation, financing, problem solving, analytical thinking and generalization. Also knowledge in psychology is unsatisfactory. There is an urgent need to give training with much higher quality. HR managers suggested that it is not the employer's responsibility to offer training on these competences because the skills and knowledge offered would be too one-sided in this case. Apart from upgrading their competencies, a more open attitude when negotiating could result from this specialized training.

There is no problem with technical competences in the educational sector. Employees in this sector are well-educated and competences like negotiation, listening, conflict solving etc. are high enough. More visible is the lack of activeness. Competencies like initiative and pro-activity need to be improved according to the HR managers' opinions in educational sector.

\subsection{Discussion about the Expectations of Estonian Human Resources Managers on ERs' Roles, Attitudes and Competences}

The relationship between employers, trade unions and employees in Estonia is dramatically changing. Globalization, economic turbulence, increasing competition, new technologies, changing world of work and employees themselves with increasing level of education are the basis for the industrial relations change. A changed world of work enables the use of more flexible forms of work (flexible hours, telecommuting, virtual work), while the demands of work, and employees' competence, work intensity and tempo is increased, increasing the amount of information necessary use for the work, and the existence of the so-called "virtual reality" in communication at work. In many cases, the borders between employees' work time and non-work time become increasingly blurred; i.e. work has become independent from the working time and also from workplace and work does not depend on working hours and the workroom (workplace) and even not on the location.

Further, in Estonia the union membership rate is 8.1\% (Statistics Estonia 2011) and $13.3 \%$ of organizations had elected trustee and organized workers council (Statistics Estonia 2011). The marginal interest of employees in their collective representation allows us to conclude that in Estonia there is a strong tendency towards workforce individualization. This situation raises the question of what employees are doing in a situation where over $80 \%$ of organizations lack both a union and a works council. Who represents them? They represent themselves without an intermediary — an individual employee must negotiate and enter into a personal 
agreement. Personal arrangements (so-called I-deals) are based on the employee's value and estimation for the organization. Our recent HR managers' study showed that $86.1 \%$ of HR managers and $85 \%$ of non-HR managers (the control group included other professionals) believe that unions don't conduct negotiations about wages; employees do it individually (Teichmann and Randmann 2013).

Working and pay conditions of a specific employee may be different to those of similar-working colleagues. Personal arrangements entered into employment agreements should be an ideal form of relationships that satisfy both parties' needs. Thus, in Estonia industrial relations are characterized by the development of a general trend towards individualization, which means that employees deal about their working conditions individually (I-deals) and submit their wishes. This leads to union membership declining, and increases workers' elected representatives (trustee) role.

If comparing survey results with the results from interviews, the disagreement in results is obvious. While the study results suggest that the Estonian ERs enjoys significantly higher empowerment by management, managers' need for control is lower, benevolence of ERs is higher, integrity of ERs is higher, and industrial relations in terms of trust are also higher in Estonia than the EU average, the results from interviews suggest opposite. While the study results suggest that Estonian employers' representatives evaluate the competencies and attitudes of the ERs quite highly and ability of ERs are assessed significantly higher in Estonia than average in Europe, the interview's results show the opposite: HR managers (members of the top management) are rather skeptical in this respect. The possible explanation for this phenomenon is:

1. Industrial relations in Estonia are characterized by the development of a general trend towards individualization, which means that employees deal about their working conditions individually (I-deals) and submit their wishes. They represent themselves without an intermediary. Personal arrangements entered into employment agreements should be an ideal form of relationships that satisfy both parties' needs. Therefore, no ERs take place in these I-deals negotiation.

2. Due to the history of trade unions in Estonia, and the way in which the union presents itself mainly as an organization, employees are convinced that when we talk about the ERs, we weren't refering to a union, but the employee-elected representatives (work councils or health and safety specialists). In the electronic survey, there was no opportunity to explain the fact that ERs referred and meant both-the union and the works councils.

3. There is a significant difference between the target groups: while the respondents of interview were members of management teams (HR top managers), the online study was more focused in employees working in HR departments (HR specialists) and/or non HR specialists in smaller companies, where the secretary or administrative assistant carries out functions of personnel management. We speculate, that those people are representing more the opinions of employee's than the standpoints of employers.

There is a big difference of ERs role depending on ownership of the company. If the owner is some large Nordic company, the corporative politics have been applied in 
corporative members as well. In these cases ERs have a more important and powerful role in enterprise. The traditions in employment relations' management are different in smaller and Estonians owned companies. Worker Councils as ERs bodies exist in organizations mainly on paper and do not have any essential influence in the organization. Managers refer once again to the need for training to be able to communicate more effectively with ERs about different and complex topics related to organizational dynamics and therefore improve trust between the parties.

As the result of interviews with HR managers in different organizations in Estonia it is obvious, that the minority of them is fully aware of the structure and functions of ERs. In many cases the respondents could not give answers to the questions concerning number of members of WCs, frequency of meetings and the main topics WCs are dealing with.

In most cases WCs exist pro forma, not having any real impact on decisionmaking process in organizations. The ERs do not participate in decision-making processes. Input for decision-making processes comes from work environment inquires. The management strives to involve all employees in decision making via open discussions and opinion polls. The WC doesn't have any special status in this process. According to the employers' opinion the current situation is satisfactory and they do not see any need for improvement mainly because of the poor competencies and low motivation of the members of work councils. HR managers stated that there is no need to engage ERs in the company's strategies, especially finance management decision-making processes.

Management tries to follow the legislation very carefully; compliance with the law is important to avoid any trouble caused by the breach of the law. Work councils as ER's bodies do exist in organizations mainly because this is an official requirement, set by law.

The issues work councils deal with mainly concern physical work environment like ergonomics, ventilation, lightening etc. The psychosocial risk factors like bulling at workplace, equal opportunities, conflicts and other factors give rise to work stress, are not under attention. This situation is going to change soon with the new redaction of Occupational Health and Safety Act, which will be approved in 2014. The managers don't admit gender equality as a problem in their companies, although there is clear evidence of the problem according to the data from studies.

Awareness of EU initiatives to promote social dialogue is very low. There is general awareness of some of them (i.e., equal opportunities on the labor market for disabled people; equal treatment of elder employees), but according to the interviews no one of the respondents was familiar with EU initiatives fully. Even if some of them were named, the comment was that these initiatives don't have the direct impact on his/her organization.

According to interview data there is no tradition in dealing with threats, social actions and strikes as there have not been any. There are some smaller problems of course, concerning workload, work environment and other issues time-to-time, but all these problems have been solved routinely. Sometimes employees react emotionally because of the poor communication, when some decisions are not communicated clearly or opinion of the employees hasn't been asked beforehand. 
Put in a wider context of Estonian labor relations, we can find some examples of social actions and strikes. These actions were initiated mainly by trade unions in economic sectors, where unions are more powerful (rail transport and healthcare). As a matter of fact these sectors were not represented in our sample. It is characteristic to Estonian labor market behavior, that employees don't take active steps to protect their rights. So-called "silent resistance" is a proper term to characterize the behavior of Estonian employees: they tend to ignore or even deny problems, and finally - if nothing changes - employees just quit and find another job, in many cases abroad. In 2005 around 5000 Estonian residents worked abroad, whereas this figure had risen to 25,000 by 2012 (Population and Housing Census 2011).

Summarizing, the trade unions movement is not popular in Estonia. From the companies participating in the interviews, trade unions exist only in three organizations from 10. These three organizations belong to the educational sector. In all these cases there is no evidence of the union providing support and guidance to the ERs. HR managers have deep doubts about unions' innovative attitude. In their opinion, unions are rather stubborn, block innovation and prevent flexibility. A minority of employees are members of a union and the union is not visible in their organizations. The reasons for such a situation are mainly historical. The unions have been an instrument of state ideology and power for more than 50 years during the soviet period. People have lost faith in unions and see them as useless. The new unions have not proved themselves yet. People believe that trade unions in their classical form and role belong to the past.

Concerning the nature of conflict management, the results from the survey and interviews are consistent: there have not been social actions and conflicts during the past years because contradictions between employers and employees have been solved cooperatively.

Open Access This chapter is distributed under the terms of the Creative Commons Attribution Noncommercial License, which permits any noncommercial use, distribution, and reproduction in any medium, provided the original author(s) and source are credited.

\section{References}

Fulton, L. (2011). Worker representation in Europe. Labor Research Department and ETUI. Produced with the assistance of the SEEurope Network. http://www.worker-participation.eu/ National-Industrial-Relations.

OECD Statistics. (2013). iLibrary. http://www.oecd-ilibrary.org/statistics.

Population and Housing Census. (2011). http://www.stat.ee/65393.

Statistics Estonia. (2011). Work Life Survey 2009. http://www.stat.ee/en. www.stat.ee/en.

Teichmann, M., \& Randmann, L. (2013). Myths among personnel (HR) professionals. European Work and \& Organizational Psychology in Practice, e-journal of the European Association of Work and Organizational Psychology (EAWOP), 5/2013, pp. 5-11. 